\title{
Identity of the Teaching Staff: Significant Events in Its Construction from the Practice of University Teaching
}

\author{
Karina Pabón ${ }^{1, *}$, Crista Weise ${ }^{2}$, Cristian Guzmán ${ }^{1}$, Verónica León-Ron ${ }^{1}$ \\ ${ }^{1}$ Faculty of Education, Science and Technology, Técnica del Norte University, 100150 Ibarra, Ecuador \\ ${ }^{2}$ Department of Evolutionary and Educational Psychology, Autonomous University of Barcelona, 08193 Bellaterra, Spain
}

Received April 30, 2020; Revised December 6, 2020; Accepted January 25, 2021

\begin{abstract}
Cite This Paper in the following Citation Styles
(a): [1] Karina Pabón, Crista Weise, Cristian Guzmán, Verónica León-Ron, "Identity of the Teaching Staff: Significant Events in Its Construction from the Practice of University Teaching," Universal Journal of Educational Research, Vol. 9 , No. 4, pp. 799 - 805, 2021. DOI: 10.13189/ujer.2021.090412.
\end{abstract}

(b): Karina Pabón, Crista Weise, Cristian Guzmán, Verónica León-Ron (2021). Identity of the Teaching Staff: Significant Events in Its Construction from the Practice of University Teaching. Universal Journal of Educational Research, 9(4), 799 - 805. DOI: 10.13189/ujer.2021.090412.

Copyright $\bigcirc 2021$ by authors, all rights reserved. Authors agree that this article remains permanently open access under the terms of the Creative Commons Attribution License 4.0 International License

\begin{abstract}
At present, higher education plays a crucial role in the transformation, construction, and development of societies. Spending time on exploring the identity configuration of teachers could generate instruction and guidance processes that should take into account their cognitive representations, discourses, and actions within their teaching practice at a personal level; The objective and intention of this study are to demonstrate how significant events of university professors have over time influenced and determined their professional identity. This research is qualitative as it follows the principles and postulates of grounded theory, which permitted the analysis and description of these events. Data collection was carried out using the SCM (self-confrontation method) through a structured interview applied professors of the faculty of education, science, and technology that voluntarily took part in this research. As part of this research, the past, present, and future of those who took part in it were explored. The speeches of these professors were analyzed under established and emerging categories with the support of the MQDA2018. The results show how significant events and people throughout both their instruction and within their professional practice have been building their identity based on these interactions. In many cases, it revealed how the discourses learned have modified in some way the development and evolution of their teaching practice, as well as within significant events, the instruction processes are unmentioned, which theoretically should help and support this preparation process of the teaching staff.
\end{abstract}

Keywords Significant Events, Teacher Training, Dialogical Self, University Teaching

\section{Introduction}

Higher education plays a very important role in the transformation and construction of societies since it generates a greater awareness in new generations regarding the importance it has for the socio-cultural and economic development of their states [24]. From this perspective, teachers are responsible for their students to meet this demand; however, different works have shown that when teachers experience situations of emotional imbalance of a negative nature, they review and rebuild their own teaching identity, which is constructed throughout their performance [27], [2] causing difficulties in their practice as teachers. Other studies show that a training process based on dramatized critical incidents generates changes in all cases in some of the dimensions of teacher identity. However, changing these practices involves overcoming a large number of obstacles of various kinds.

The performance of a doctor, lawyer, engineer, social communicator or artist in the classroom, is not the same as the one of a professional with pedagogical formation. It requires different skills that allow students to face real-life problems, rather than the acquisition of purely academic content [18]. But when this does not happen, it is seen how 
these professionals carry out teaching activities that perhaps in most cases are reproduced only by remembrances of what their teachers did when they were students, being careful not to make the same mistakes they thought their educators were committing. As mentioned by Darling-Hammond [8] this is an important subject within the universities because the challenges that these professionals face daily grow in number and difficulty; therefore, educational institutions are obliged to support their teaching staff, and in the case of new professionals, ensure their inclusion and follow-up in an appropriate way.

To generate a training model for these professionals to be adequately incorporated into their new role would mean changing the way of seeing "training" and understanding it from a more holistic approach to encourage participants to build this new identity and, above all, be able to demonstrate the elements that constitute it [1].

Taking into account that teachers convey knowledge, skills, and values to the mass population [18], it is of great importance that a formation plan for teachers that consider their cognitive representations, discourses and actions on their teaching practice at an individual level [5], which would allow a conscientious reflection on their professional practice and recognition of their different positions regarding their role, the existing ones, new and possible I positions (decentralized movements) define the identity of a university teacher, in effect, achieving what Darby [7] affirms, a change will only be deeply assimilated and consolidated if it is accompanied by a new way of feeling as a teacher.

Professional identity is an essential construct to understand educational institutions and what happens in them [9], while the formation of a teaching identity takes place within social, organizational, and sociohistorical circumstances [25]. The development of a teacher's identity is a continuous and multifaceted process. Becoming a teacher is an ongoing project of formation and reform within an elaborate network of membership, institutional, discursive, and natural elements settings [22]. Therefore, moment-to-moment interactions with students, colleagues, annual changes in responsibilities, and continuous accompaniments have the potential to push the path of a teacher's identity [24].

In Ecuador, there is no research focused on the change of educational practices from the conceptions, beliefs, and strategies that a teacher already has. Attempts to change educational practices, as in Spain, are aimed at instructing the teachers to fulfill bureaucratic demands; that is, lesson plans, virtual classrooms, complementary hours and reports of their teaching activity and the training itself, has been kept in the background and only through traditional formats (conferences, courses, and workshops taught by experts) [17]; achieve a reflection process to generate identity changes in teachers requires the support of theories that facilitate the understanding of these processes. Thus, mentioning the Dialogical Self Theory (DST) and recent trends in educational research aim to overcome the traditional cognitive approach and encompass a broader vision of the educational mission, particularly in formal contexts such as schools [14].

The core of this research is based on the Dialogical Self Theory [11], in whose contribution identity is conceived as a mental mini-society in which different positions of oneself have their voice and generate narratives that compete, causing some of them to prevail or on the contrary, producing changes that permit new positions to be elaborated; allowing professionals to interact in their new role as teachers creating both their own and adopted representations, depending on the context: with students, colleagues, managers, family, etc. They have generated a certain type of action and sense assigned to "be a teacher" and "be a teacher of that subject" [16]. From this perspective, it can be said that their actions, responses, and attitudes will depend on how they, from their corresponding I position, react to certain contexts [21].

Achieving these changes in the identity of a teacher requires constant reflection on their identity through dialogue. For example, Ketelaar [12] analyze how teachers speak with different voices rather than with their own, in a school situation where they want to introduce certain changes linked to the teaching of innovation. It is precisely the discontinuous nature of identity that favors changing the positions of the self in response to the particular conditions of the contexts [5].

Therefore changing the identity implies changing the implicit from which the teacher acts, making possible an interpretation of the problem from other angles. Consequently, trying solutions that lead to lasting changes [26] can be achieved by analyzing the events that teachers face.

It is proposed to demonstrate how significant events influence the formation of the identity of educators, how these recall past experiences and integrate them into their current practice. Thus generating a new vision regarding the issue of teacher training, since theoretically the need to change these processes and make them more relatable to real needs is sustained.

\section{Methodology}

This study is qualitative with a descriptive and interpretive design in which the professionals' accounts of their significant experiences are analyzed, using a method common to the theory applied in this research.

\section{Participants}

This study was carried out with the voluntary collaboration of 10 professors: four female professors, and six male professors of "Técnica del Norte" University of the different faculties that comprise it; Faculty of 
Education, Faculty of Administration, Faculty of Health Sciences and two faculties of Engineering. The selection criteria were: tenured teachers with more than three years of experience in university teaching, with and without training in pedagogy.

\section{Process}

The self-confrontation method questionnaire was used [10], which is a method proposed by the Dialogical Self Theory [15] which allows the location of the interviewees in the past, and future through seven open-ended questions. There are two questions about the past, two about the present, and three about the future. These questions are unstructured and motivate the interviewees to consider significant events regarding their role as university teachers. These interviews were carried out individually with a team of four psychologists with a duration of approximately 30 minutes per participant.

For data analysis, the MAXQDA software (Analytics pro 2018) was used, this identified segments that served to define the different categories.

The categories analyzed to describe significant events were as follows.

Table 1. Analysis categories

\begin{tabular}{|c|c|}
\hline \multirow{2}{*}{ People } & Past \\
\cline { 2 - 2 } & Present \\
\cline { 2 - 2 } & Future \\
\hline \multirow{2}{*}{ Events } & Past \\
\cline { 2 - 2 } & Present \\
\cline { 2 - 2 } & Future \\
\hline Discourses Learned & $\begin{array}{c}\text { Which are currently applied in their } \\
\text { teaching practice. }\end{array}$ \\
\hline
\end{tabular}

Once the interviews were individually analyzed, three narratives were selected based on compliance with the established categories. The category of "People" describes the function, influence, or fundamental role these individuals had in the interviewees to become university professors in their past, present and, future, likewise the events in their life; while the learned discourses are reflected as learned voices applied in their teaching practice.

\section{Findings}

This section described how people and events have influenced the formation of these teachers' identity, and how these educators rediscover the voices of past experiences and integrate them into their current practice.

The interviewees were asked to locate themselves in their past, present, and future and to try to remember if there was any person or persons, experiences, or events that meaningfully influenced their professional life and, even now, significantly affects their current performance. As open questions, they allow teachers to reflect on their life in a temporal context and interact dialogically with other significant people.

Below are the different discourses by categories of analysis:

\section{Person / People from the past}

\section{Teacher 1}

"I was very struck mmm well, with the way he taught classes, I was very struck by the publications, the subjects he was dedicated to, actually he did not tell me anything specifically, in fact, he was quite serious let's say so, but I, I liked that image of a teacher that I saw in him".

\section{Teacher 2}

"My mom because she was the first person whom I told that I wanted to be a teacher because at the beginning I was studying another major... she has been the fundamental pillar she is the one who continues to be my pillar she is the one who is always encouraging me and supporting me to keep going so I can continue to develop as a teacher in the best way."

\section{Teacher 3}

"My teachers, teachers with a lot of experience, who knew how to empower me in the teaching profession and they left me a very important legacy which I use to always guide myself with ethics and with values and principles that allow, mmmm, to always safeguard the well-being of my students not only in the academic area but also in the human area".

\section{Person / Persons of the present}

\section{Teacher 1}

"Ok, here, I know many teachers who get my attention as they teach their classes, who can get my attention as they are always from one place to another, publishing researches and articles, so I do not know if I have said a name; there are some who motivate me just by seeing how they are growing professionally".

\section{Teacher 2}

"Currently my greatest source of inspiration is my children and I try to be an example not only as a mom but also as a professional because I want them to succeed later as professionals and do things well".

\section{Teacher 3}

"My mother is a fundamental pillar, but those who motivate me every day when I get up, amid the bad nights we have, the activities we do, are my students, who motivate me a lot are my students". 


\section{Person / People of the future}

Teacher 1

"My wife and my children are my permanent motivation because ... I think it is a very beautiful profession and that with it I can also convey many things to them because I always think that as they grow up, I can teach them things and I know there are many ways to empower them though they don't tell me anything, the fact that they are there for me is my motivation".

Teacher 2

"Well, with the blessing of God, who is the only one who gives us health and life. The person who I want always by my side, close to me, is my husband ... as he is the one who is always by my side, whatever, any difficulty, any problem, eh. that we have any situation that comes up to us daily we try to solve it together and I would like him to be by my side

Teacher 3

"My wife, I want my wife to be there with me, to be the wife of the teacher and to be the wife of the retired teacher ... and go through this hard work of teaching because she understands my needs, I understand her concerns, we share this beautiful, and nice profession and I wish it could always be like this".

\section{Significant events of the past}

Teacher 1

"So as I tell you, it would be in the master's degree where I served as a teacher's aide, that motivated me, before that, I had jobs where I could be doing workshops and that kind of thing, and it strongly caught my attention the part when I had the opportunity to be a teacher's aide emm I think that this was the biggest decision because I saw that it was something that I liked and being able to convey something that got to be known in this way".

\section{Teacher 2}

"Since the first year they took us to teaching practice so what I always remember is that I went directly to educational institutions especially there were the children centers ... then I fell in love with everything I saw and it is something that I always have in my head and it is the reflection that I always do and that is why I am here currently in the university ".

\section{Teacher 3}

"My interest in teaching began in the university, definitely there was a teacher who marked a before and after in my life compared to what I thought to study ... when you see that a teacher is passionate, he was very passionate with what he did because he was happy in the classroom, he was fun and very correct in his actions, in his principles, and his ethics when dealing with his students and at being, considering that we are human and that treatment should be individualized for each student ".

\section{Significant events of the present}

\section{Teacher 1}

"Well, actually, the abrupt change that marked a little was the change of processes, from a private university to a public university, it is always something different, as processes are handled differently. Let's say, a little more complicated, more people, more persons, different types of thoughts ..." ".

\section{Teacher 2}

"Every day at university there is an incredibly strong demand, and that demand makes you continue improving... it makes you demand of yourself to be able to deliver positive things to the students and the same way requires them to comply with things ... ".

\section{Teacher 3}

"Well, yes professional experience marks a little because in the majors where I work are majors of other fields so the subjects that I am teaching right now are basic and I have seen that students do not take much account of these basic subjects, they are more interested in major-specific subjects, so it is a bit difficult because even when it is thesis advising, I have thesis advising for topics that are directly framed in what my professional area is, so I do feel a bit relegated..."

\section{Significant events of the future}

\section{Teacher 1}

"... I think the quality of life is important and the time that one can have with family and people that one loves, and a job should not absorb everything so if the work due to changes or other reasons would become like that then, I would decide to quit ... I think that if at some point my job would become that, that would be the limit I would reach".

\section{Teacher 2}

"The educational reforms have been the requirement of competitiveness ... having a doctorate ... I'd say, I don't know, for me to be able to decidedly continue in the university you have to study the doctorate, it can be a factor".

\section{Teacher 3}

"Something that could influence the future that would be out of my control would be my health, although I try to have a physical and emotional balance because we wear ourselves out throughout the semester... also, I don't know, the policies in the higher education law". 


\section{Discourses learned}

Teacher 1

"I had a teacher, I remember in those times, he liked poetry a lot so he always assigned us to read and so little by little I also liked poetry, he always said: you have to read, you have to read, you know not what you may miss ... So I tell my students now: you have to read, you always have to read and review research in the field, and when we discuss it in class, I tell them: you see we almost missed something important"

\section{Teacher 2}

"If you are not going to do it well, don't do it, I believe this applies to students and it is something that I can tell them: if you are going to do something well, do it well and I even say that to become a teacher, you have to be a good teacher, and if you don't want to be good, I would rather want you to be a bad teacher than being called a mediocre one, that is to say half-heartedly yes. I always direct them because I am looking for excellence and I tell them: I know they are good but excellence is something that I take with me from my mother who always told me to do things right, otherwise do not do them."

\section{Teacher 3}

"... But he was very funny when sharing with his students without breaking that thin thread of respect between student and teacher, he always had something very amusing to do... the vision he had to teach, was very entertaining, always very amusing about anything he had, he had something funny to say, he knew that exact moment to make us feel different and it was that fun, happy way of working in the classroom...".

"If, now I am like this, it is because I love to have fun, and you know that I really like to have a good time like this because, with students, you have no idea how satisfying it is for me to see them smile feeling good with their teacher because it is.. .it is so gratifying ... we stop and laugh for a moment, I make them smile at any situation and we continue".

In summary, it can be observed that these teachers throughout their lives as university professors and even during their professional formation, have been storing significant events with their own voices, which have permitted them to interact in their role as university professors creating own and adopted representations, depending on the context: with students, colleagues, managers, family, etc. In this sense, Monereo [16], show how these type of interactions generate a certain type of action and meaning to "be a professor" and "be a university professor", thus allowing the construction of a dynamic, committed and humanistic identity, features that are reflected in the different discourses and their teaching practice.

\section{Discussion and Conclusions}

This study aimed to demonstrate how significant events influence the formation of the identity and practice of teachers. Based on the results, it is concluded that promoting moment-to-moment interactions with students, colleagues, annual changes in responsibilities, and continuous accompaniments have the potential to push the path of a teacher's identity, as demonstrated by Van Rijswijk [24]. It is also observed that within these significant events the training processes are not mentioned, which theoretically [3], should assist in teacher formation; that is why generating spaces where teachers can share their various coping strategies to incidents they may have in the classroom [26], means opening possibilities for change, and whose identities are compelled into generating processes of reflection, learning and deeper understanding of the critical incidents involved.

Bakhtin [6], recognizes that other voices and discursive repertoires are incorporated for the appropriation of a pedagogical discourse, which implies that the more exposed teachers are to voices that enrich their identity as university professors, the higher the probability that their current positions are modified to be in harmony with what they conceive as university professors and with what they are [19].

Hermans \& Thorsten [11], recognize identity as a system of both an individual (intrapsychological) and a social (interpsychological) nature, in which the human beings construct their identity in interaction with the context, through the negotiation of meanings, dialoguing with themselves and with others, to interpret, understand and explain who is being, in a certain time and space; what can be observed in each one of the answers of the interviewees.

The method of self-confrontation [15], allows us to approach the process of construction of the personal meaning of individuals from their self-reflection and organization of historical events and emotionally relevant experiences with coherent and intelligible narrative structures; In the case of this research, open-ended questions allowed participants to reflect on their life in a temporal context and interact dialogically with other significant people, in addition to the past and future self. From this perspective, it can be said that their actions, responses, and attitudes will depend on how they, from their corresponding I positions, react to certain contexts [21].

This research obliges [13],[19], [20] to rethink the teacher training process since the number of teachers is increasing every day along with the challenges that these professionals in their practice must face daily; therefore, educational institutions are compelled to support their teaching staff in this regard and, in the case of new professionals, seek their insertion and follow-up in the most appropriate way. 
Finally, the data show that there are voices that are reflected in practice and decision-making within the professional practice of the university professor. So it is time to restructure the formation processes known as training, thus generating voices that would significantly determine the development of teacher identity as described by Aveling [4] and as evidenced in this research.

\section{REFERENCES}

[1] Aguayo, M., Castelló, M., \& Monereo, C. (2014). La identidad del académico de enfermería: Entre la docencia y la investigación. TextoContextoEnferm, 23(2), 241-249.

[2] Albores, A., Porras, A., \& Carmen, V. (2016). La identidad docente de los profesores de educación media superior . El caso del colegio de bachilleres de Chiapas. Revista Latinoamericana de Estudios Educativos, XLVI N3, 157-170.

[3] Alsup, J. (2006). Teacher identity discourses: Negotiating personal and professional spaces. Mahwah, NJ: Lawrence Erlbaum.

[4] Aveling, E.-L., Gillespie, A., \& Cornish, F. (2015). A qualitative method for analyzing multivoicedness. Qualitative Research, 15(6). https://doi.org/10.1177/146879 4114557991

[5] Badia, A., Liesa, E., Monereo, C., \& Weise, C. (2017). Re-thinking Identity in Education: A dialogical Perspective . (Work in progress), 1-12.

[6] Bakhtin, M. (1984). Problems of Dostoevsky's poetics. (C. Emerson, Ed. \& Trans (University). Minneapolis.

[7] Darby, A. (2008). Teachers' emotions in the reconstruction of professional self-understanding. Teaching and Teacher Education, 24(5), 1160-1172. https://doi.org/10.1016/j.tate. 2007.02.001

[8] Darling-Hammond,L. \& Bransford, J. (2005). Preparing Teachers for a Changing World. What Teachers Should Learn and Be Able to Do (Jossey-Bas). San Francisco.

[9] Gee, J. P. (2001). Identity as an Analytic Lens for Research in Education in Education Identity as an Analytic Lens for Research. American Educational Research Association, 25, 99-125. https://doi.org/10.3102/0091732X025001099

[10] Hermans, H. J. M. and Hermans-Jansen, E. (1995). Self-Narratives: The Construction of Meaning in Psychotherapy (The Guilfo). New York.

[11] Hermans, H., \& Thorsten, G. (2012). Introductory chapter: history, main tenets and core concepts of dialogical self theory. En Handbook of Dialogical Self Theory (University, pp. 3-22). Cambridge.

[12] Ketelaar, E., Beijaard, D., Boshuizen, H. P. A., \& Den Brok, P. J. (2012). Teachers' positioning towards an educational innovation in the light of ownership, sense-making and agency. Teaching and Teacher Education, 28(2), 273-282. https://doi.org/10.1016/j.tate.2011.10.004
[13] Lara, B., Henríquez, V., \& Villarroel, Y. (2020). Voces de la identidad de estudiantes de profesorado. Revista de Estudios y Experiencias en Educación, 19(0717-6945), 211-221.

[14] Ligorio, M. B. (2012). The dialogical self and educational research: a fruitful relationship. En Handbook of Dialogical Self Theory (University, pp. 439-453). Cambridge.

[15] Lyddon, W. J., Yowell, D. R., \&Hermans, H. J. M. (2006). The self-confrontation method: Theory, research, and practical utility. Counselling Psychology Quarterly, 19(1), 27-43. https://doi.org/10.1080/09515070600589719

[16] Monereo, C., Badia, A., Bilbao, G., Cerrato, M., \& Weise, C. (2009). Ser un docente estrategico: cuando cambiar la estrategia no bastaBeing a strategic teacher: When changing strategies is not enough. Cultura y Educaci\&\#243, 21(3), 237-256.

[17] Monereo, C., Weise, C., \& Alvares, I. (2014). Cambiar la identidad docente en la universidad. formación basada en incidentes dramatizados. Infancia y Aprendizaje: Journal for the Study of Education and Development, 36(3), 323-340. https://doi.org/10.1174/021037013807533043

[18] Nasri, N. M., Yusof, Z. M., Ramasamy, S. A. P., Halim, L., \& Ming, L. W. (2011). Personal constructs: Novice and expert science teachers concerning teacher function. Procedia - Social and Behavioral Sciences, 15, 2823-2826. https://doi.org/10.1016/j.sbspro.2011.04.196

[19] Pabón, K., .Weise, C., Posso, M., Narváez, G., León, V., \& Guzmán, C. (2018). La identidad del docente universitario desde un enfoque socio-cultural y su influencia en el proceso de enseñanza-aprendizaje. Psicologíaen la educación, II(978-9942-784-64-3), 50-57.

[20] Ruvalcaba-Coyaso, J, Uribe A., I. \&, \& Gutiérrez G., R. (2011). Identidad e identidad profesional: Acercamiento conceptual e investigación contemporánea. Revista CES psicología, 4, 82-102. https://doi.org/ISSN: 2011-3080

[21] Scartezini, R. A., \& Monereo, C. (2016). The development of university teachers??? professional identity: a dialogical study. Research Papers in Education, 1522(September), 1-17. https://doi.org/10.1080/02671522.2016.1225805

[22] Settllage, J., Southerland, S. A., Smith, L. K., \& Ceglie, R. (2009). Constructing a doubt-free teaching self: Self-efficacy, teacher identity, and science instruction within diverse settings. Journal of Research in Science Teaching, 46(1), 102-125. https://doi.org/10.1002/tea.20268

[23] UNESCO. (1998). Declaración mundial sobre la educación superior en el siglo XXI: Visión y acción. Conferencia mundial sobre educación superior, 141. Recuperado de http://unesdoc.unesco.org/images/0011/001163/116345s.pd $\mathrm{f}$

[24] Van Rijswijk, M. M., Akkerman, S. F., \&Koster, B. (2013). Student teachers' internally persuasive borderland discourse and teacher identity. International Journal for Dialogical Science, 7(1), 43-60.

[25] Varelas, M., House, R., \& Wenzel, S. (2005). Beginning teachers immersed into science: Scientist and science teacher identities. Science Education, 89(3), 492-516. https://doi.org/10.1002/sce.20047

[26] Weise, C., \& Sànchez-Busqués, S. (2013). Identidad docente 
y estrategias de resolución de incidentes críticos en contextos universitarios de alta diversidad sociocultural.
Cultura y Educacion, 25(4), 561-576. https://doi.org/10.108 $0 / 11356405.2013 .10783162$ 